\title{
PENDIDIKAN TASAWUF DALAM PEMBENTUKAN KECERDASAN SPIRITUAL DAN AKHLAKUL KARIMAH
}

\author{
A.Gani \\ ainulghani@radenintan.ac.id \\ Universitas Islam Negeri Raden Intan Lampung
}

\begin{abstract}
This study examines how Sufism education in forming the spiritual intelligence and akhlakul karimah. This study is one of the research literature(LibraryResearch). The analysis technique which is used in this study is descriptive analysis. Sufism education offers a solution to human problems today, in forming spiritual intelligence and akhlakul karimah. Sufism education material teaches human to repent, put on trust, wara', zuhud, patience, tawakal and ridha. Some of these maqamats must be carried out by human and practice the sunnah fasting, dzikir, istighfar, istighatsah and muraqabah. Thus, makes the human soul that full of defilements will automatically clear again, the spiritual intelligence can be formed in the brain and controled the implementation of akhlakul karimah. The existence of spiritual intelligence formation and akhlakul karimah can make human not easily affected by the lust from the world grandeur.
\end{abstract}

Keywords: Sufism Education, Spiritual Intelligence, akhlakul karimah.

\begin{abstract}
Abstrak
Penelitian ini mengkaji bagaimana pendidikan tasawuf dalam pembentukan kecerdasan spiritual dan akhlakul karimah. Penelitian ini merupakan salah satu jenis penelitian kepustakaan (Library Research). Teknik analisis yang digunakan dalam penelitian ini menggunakan deskriptif analisis. Pendidikan tasawuf menawarkan sebagai solusi permasalahan-permasalahan manusia saat ini, untuk membentuk kecerdasan spiritual dan akhlakul karimah. Materi pendidikan tasawuf mengajarkan manusia untuk bertaubat, bertawakal, memiliki sifat wara, sifat zuhud, sabar, tawakal dan ridha. Beberapa maqamat tersebut harus dijalankan manusia serta mengamalkan puasa sunah, dzikir, istighfar, istighatsah dan muraqabah. Maka jiwa manusia yang sebelumnya penuh dengan kekotoran akan dengan sendirinya jernih, otak akan terbentuk kecerdasan spiritual yang mengendalikan dengan penerapan akhlakul karimah. Adanya pembentukan kecerdasan spiritual dan akhlakul karimah, manusia tidak mudah tergoda dengan hawa nafsu kemegahan dunia.
\end{abstract}

Kata Kunci : Pendidikan Tasawuf, Kecerdasan Spiritual, Akhlakul Karimah 


\section{PENDAHULUAN}

Masyarakat abad 21 mengalami transformasi dalam bidang pengetahuan dan teknologi menuju ke arah modern. Dua sisi arah modern memberikan kemudahan manusia dan menenggelamkan manusia dalam keterpurukan. Eksistensinya pengetahuan manusia dalam berkarya menghasilkan pembaharuan teknologi yang lebih maju. Rasa haus manusia dalam melahirkan pembaharuan teknologi, memiliki asumsi bahwa dirinya adalah Tuhan. Asumsi tersebut mendoktrin bahwa Tuhan tidak penting dalam kehidupan, karena dirinya sudah mampu menciptakan sesuatu sesuai dengan keinginan. Dengan ditandainya memisahkan ilmu pengetahuan dengan agama, menganut paham sekuralisme, yang menggunakan metode ilmiah dari perpaduan rasionalisme, empirisme, dan positivisme dalam satu paket epistimologi.(Ubaedillah 2015) Bukan hanya ilmu pengetahuan dan teknologi yang berkembang di Abad 21 tetapi bidang ekonomi, hukum, politik, sosial, budaya dan pendidikan berkembang pesat (Ali Maksum 2003)

Hasil teknologi yang disebar luaskan, mewarnai kancah dunia Internasional, memiliki respon apresiasi yang baik oleh masyarakat. Teknologi tersebut membuktikan kepada masyarakat, bahwa saat ini semuanya dapat dicapai dengan mudah. Masyarakat berlomba-lomba untuk mengikuti kemajuan zaman. Android sebagai bukti alat perkembangan teknologi di abad 21, memberikan kemudahan masyarakat dalam jualbeli, mencari informasi, menuntut ilmu dan sebagainya dengan android. Disisi lain dari kemudahan menimbulkan efek negatif. Berita-berita di media suadah tidak asing lagi, seorang istri membunuh suaminya, seorang anak membunuh bapaknya, para pejabat yang koruptor, para pembisnis yang kecanduan narkoba, anak kecanduan game sampai meregang nyawa, terjadinya kejahatan seks bebas, pencurian, pembunuhan, kejahatan media sosial, dan sebagainya. Terjadinya peristiwa tersebut karena jiwanya belum mampu menyikapi kemajuan zaman, salah kaprahnya dalam menanggapi kemajuan zaman. Karena lemahnya spiritual dalam diri manusia, kurang mendidik diri sendiri dengan nilai-nilai spiritual serta mengamalkan, dan lupa dengan sang Pencipta. Hawa nafsu yang terus menjadi obsesi jiwa bukan rasa syukur yang terus terisi dalam jiwa. Hati yang terus terus tergerogoti oleh kekuasaan dan keindahan, menjadikan hati yang kotor menjulur merusak otak dan melakukan tindakan yang tercela. 
Peristiwa yang ada menjadi bukti pentingnya dalam kehidupan untuk menanamkan nilai-nilai spiritual, ketika nilai-nilai spiritual tertanam dalam hati maka pikiran akan bertindak lebih berhati-hati dalam bertindak. Bahwa kebahagiaan bukan dicapai dari uang, jabatan, kekuasan dan keindahan, tapi kebahagiaan dicapai melalui spiritualitas, maka kebahagiaan yang lain akan mengikuti dengan sendirinya. Hasil dari spiritualitas manusia yaitu implementasi akhlakul karimah dalam kehidupan. Ketika manusia terobsesi dengan dua hal tersebut (spiritualitas dan akhlak),maka akan melahirkan hati yang tenang, bersih, nyaman, bersyukur dan menikmati hidup walaupun ada banyak masalah yang terjadi.(Ahmad Muttaqin 2014)

Kecerdasan spiritual dan akhlak dalam diri manusia dapat dibentuk melalui pendidikan tasawuf. Dengan pendidikan tasawuf, manusia mengenal ilmu untuk mensucikan jiwa yang membersihkan hati, untuk tunduk kepada ketentuan Allah Swt. dan mengimplementasikan dengan akhlakul-karimah sebagai cara untuk mendekatkan diri kepada Allah Swt.(Sutomo 2014) Manusia dididik untuk menanamkan akidahnya, dengan berpedoman kepada Al-Qur'an dan As-Sunnah, melalui Syari'ah. Selanjutnya, manusia untuk menuju jalan ibadah dengan mengistiqomahkan yang wajib, membiasakan yang sunnah dan menajuhi larangan syariat Allah melalui Thariqah. Tingkatan haqiqah, manusia menempuh jalan spiritual dalam mencapi hati atau batinnya melihat kebesaran Allah dan ma'rifat tingkatan terakhir, manusia mampu menghadirkan Allah.(Suryaningsih 2013)

Mencapai tingkatan di Thariqah, dapat membentuk kecerdasan spiritual manusia. Manusia dibimbing untuk istiqomah dalam menjalankan tingkatan yang telah dituliskan oleh Imam al-Ghazali yaitu taubat, sabar, zuhud, ridha, tawakkal, mahabbah dan ma'rifah. Kecerdasaran spiritual akan terbentuk didalam jiwa dan hati untuk melaksanakan amalan-amalan istighfar, dzikir, shalawat Nabi, puasa, muraqabah, Ataqah, Hizib dan sebagainya.(Al-Haramain 2011) Dari amalan-amalan tersebut akan membentuk akhlakul karimah dalam diri manusia. Ketika kecerdasan spiritual dan akhlakul karimah sudah terbentuk maka manusia dapat menanggapi zaman saat ini, memilih yang baik atau tidak, meredam hawa nafsu dan bijak dalam memanfaatkan teknologi dalam kebaikan. Perlunya untuk dibahas, "Pendidikan Tasawuf dalam Membentuk Kecerdasan Spiritual dan Akhlakul Karimah.” 


\section{METODE PENELITIAN}

Penelitian ini merupakan salah satu jenis penelitian kepustakaan (Library Research). Peneliti memperoleh hasil penelitian dari perpustakaan, kemudian dari bukubuku tersebut dikumpulkan untuk dibaca lalu mencatat hasilnya yang berkaitan dengan pembahasan dan permasalahannya.Teknik analisis yang digunakan dalam penelitian ini adalah deskriptif analisis.

\section{HASIL KAJIAN DAN PEMBAHASAN}

Abad 21 manusia berada pada zaman yang maju dalam segi ilmu pengetahuandan melahirkan teknologi-teknologi baru. Para intelek-intelek atau ilmuwan barat berlombalomba dalam mencurahkan pemikirannya, untuk menghasilkan sebuah teknologi dalam mengembangkan atau menciptakan yang baru. Dari tahun ke tahun perkembangan teknologi semakin apik dan memiliki banyak apresiasi dalam dunia Internasional, memberikan rasa haus untuk terus menciptakan. Abad 21 bukan masa awal dari lahirnya modernisasi, tetapi abad 21 pada zaman kemajuan ilmu pengetahuan dan teknologi yang bersaing di era modern. Pada abad ini era modern menyebar secara pesat seluruh negeri, tidak hanya Barat saja. Pernyataan Arnold Toynbee terkait lahirnya modernitas sudah ada sejak abad 15 yaitu ketika orang Barat sudah mampu dengan keberhasilan dirinya tidak mengucapkan terimakasih kepada Tuhan tetapi berterimakasih kepada dirinya yang telah melahirkan banyak karya yang hebat (Yulianto 2015).

Mohammed Arkoun cendikiawan muslim yang membantah pendapat Arnold Toynbee, bahwa modernitas berasal dari bahasa Latin "modernus", kata modernus muncul dari kalangan Kristen yang digunakan untuk menunjukkan masa perpindahan dari masa romawi sampai ke periode Masehi, pada tahun 490 dan 500 M. Adanya perbedaan pendapat, Suadi Putro mengemukakan bahwa pendapat keduanya sebuah kebenaran, hanya penetapan arti modernitas yang berbeda. Terdapat keterkaitan modernitas pada masa kuno (Yunani dan Romawi) dengan abad pertengahan. Pendapat Arkoun sebagi kelanjutan kemajuan di Yunani Semit. Selanjutnya pengaruh Yunani melalui gelombang Helenisme terhadap kemajuan pesat di dunia Islampada abad ke-7 sampai ke-12. Dan perubahan tersebut mempengaruhi duni Kristen pada abad ke-12 sampai ke-15 pada zaman kejayaan Skolastik (Suadi Putro 2000). 
Kemodernan pada Abad 17, Antony Giddens memaknai modernisme atau modernitas yaitu pola hidup sosial masyarakat, yang terlahir di Eropa. Pada abad ini kemodernan mulai merambah ke berbagai Negara. Sedangkan Lawrence Cahoone memaknai kemodernan sebagai ide, prinsip, dan pola interaksi dari berbagai bidang, mulai filsafat, ekonomi, kesehatan, pendidikan dan seterusnya. Kemodern bidang tersebut, menjadi dasar perkembangan masyarakat dan kultur Eropa Barat dan Tengah serta Amerika, sejak abad ke-14 sampai ke-20 (Emmanuel Wora 2006)

Android sebagai bukti lahirnya kemajuan ilmu pengetahuan dan teknologi di abad 21. Penemu android, yang terus mengembangkan fitur-fitur yang lebih menarik berasal dari dunia barat atau non muslim. Tentunya sebagai masyarakat muslim untuk berhatihati dengan teknologi ini, karena setiap pengembangan suatu teknologi terdapat tujuan positif dan tujuan negatif. Penyalahgunaan android bagi anak-anak sampai orang dewasa dapat menimbulkan bahaya, karena tidak bijaksana dalam menyikapinya. Pada anak-anak, jika tidak diawasi dalam penggunaan android dapat memberikan kecanduan game mengakibatkan sulit untuk bersosialisasi, gangguan mental, bahkan kejiwaannya dapat terganggu. (Suciati, 2013). Mengkonsumsi film porno atau vidieo porno, rasa ketagihan itu terus menggelayut dalam pikirannya dan menimbulkan kecanduan pada remaja. (Novita 2018). Kejahatan dalam media sosial seperti facebook, sebagai alat kejahatan seksual anak remaja (Husen Mony 2015). Media sosial sebagai alat pemecah belah rumah tangga, terjadinya perselingkuhan, kecemburuan dan menimbulkan perceraian (Prasanti and Indriani 2018).

Seyyed Hossein Nasr mengungkapkan era modern terjadi krisis spiritual, karena manusia telah kehilangan pengetahuan tentang mengenal dirinya, keakuan yang senantiasa dimilikinya, menderita penyakit pelupa tentang siapa dirinya, dan krisis keksistensial dari pemberontakan manusia modern terhadap Tuhan-Nya. (Din Wahid 2003) Visi keilahian sudah hilang dalam abad ini, telah tumpul penglihatan intellectusnya dalam memahami keberadaan keakuan pada dirinya dan hilangnya mata batin yang mengakui realitas sang Pencipta (Haryati 2012). Roger Geraudy mengungkapkan dari kelimpahan kekuasaan ilmu pengetahuan, yang memuaskan penciptaan teknologi sebagai eksistensi dunia, sesungguhnya manusia modern dalam keadaan miris yaitu tidak mampu menjawab persoalan-persoalan hidupnya sendiri, yang terjadi dan mencari 
pengisi dari sesuatu yang kosong, jiwa yang gersang dengan kembali kepada nilai-nilai spiritualitas yang pernah dikesampingkan (Roger Geraudy 1989). Pencapaian kehidupan dunia tidak memberikan kemaknaan suatu kehidupan. Ke-modern-an yang dianggap sebagai solusi dari kematian ilmu pengetahuan dan teknologi, kini hidup kembali dengan memberikan berbagai fitur kemudahan dan spiritualitas diabaikan. Pada akhirnya memberikan keadaan yang berada pada bayangan semu (Sidqi 2015).

Hidup yang tidak bermakna dari keterlenaan kecanggihan teknologi, belum mampu bijak dalam menggunakan atau menyeimbangkan keberadaan teknologi memberikan akhir keterpurukan manusia. Permasalahan yang terjadi memberikan kerendahan diri, kekosongan hati, memberontaknya jiwa, rasa putus asa dan rasa ingin mengakhiri hidup. Kejadian ini karena jiwa dan hatinya tidak tertanam spiritual. Nilainilai spiritual dan akhlak pada mulanya diacuhkan dengan dikesampingkan, bahkan tidak diperlukan. Hawa nafsu yang terus bergejolak dalam pemuasan dunia memberikan kegelapan pada titik akhirnya. Pemuasan uang sebagai tujuan hidup manusia, yang menganggap uang adalah segalanya bagi manusia maka manusia mentotalitaskan seluruh jiwa raganya dalam mencari uang. Melalui haus akan jabatan, kekuasan tertinggi, berbisnis yang maju, demi menggapai uang. Peristiwa pertama, manusia telah menggapai semuanya tetapi pada akhirnya merasakan kekosongan hati, jiwa yang tidak tenang, tidak adanya keakraban dalam keluarga, hilangnya sosialisasi di masyarakat, maka manusia akan kembali mencari spiritualitas untuk mencapai kebahagiaanya.

Peristiwa kedua, manusia telah menggapai jabatan dalam kekuasaan, disisi lain ada penuntutan dari keluarga untuk menuruti nafsu benda-benda mewah, karena melihat ekonomi sendiri yang kurang maka melakukan tindakan korupsi. Memuaskan dunia dengan korupsi pada akhirnya tertangkap dan berakhir di jeruji besi, akibatnya keluarga dalam keadaan carut-marut, kebahagiaan hilang. Pada masa ini, maka manusia akan kembali untuk mencari nilai-nilai spiritualitas. Peristiwa ketiga, manusia telah menggapai apa yang diinginkan, uang yang melimpah, dengan jabatan tertinggi, bendabenda mewah menghiasi kehidupan. Pada masanya tiba mengalami kelengnseran jabatan, bisnis yang bangkrut dan mengalami penurunan uang, tidak mampu memenuhi pengeluaran sehari-hari. Maka yang terjadi, rumah tangga yang berantakan, anak yang menjadi korban dalam kekacuan, uang yang didambakan dulu sekarang hilang. Kejadian 
ini manusia akan kembali pada titik mencari niali-nilai spiritual, untuk kembali menata kehidupan.

Pemuasan media sosial sebagai satu-satunya alat yang paling dipentingkan manusia, bagi anak remaja yang terlena dalam menyikapi media sosial. Facebook bagian dari media sosial yang memberikan kemudahan dalam berkomunikasi jarak jauh, banyak fitur yang tersedia dapat berbicara dengan melihat fisik satu sama lain. Dapat mengeshare sesuatu dan membuat status sebagai ranah memudahkan dalam berdagang online. Tetapi kemudahan tersebut memberikan perspektif yang berbeda bagi anak remaja atau orang dewasa.Peristiwa pertama, bagi anak remaja yang masih pada masa pubertas. Masa ingin terlihat cantik ataupun ganteng, masa ingin diperhatikan, masa ingin melihatkan kehidupannya, masa ingin mencari kenyaman dan lain sebagainya. Facebook dijadikan ajang perlombaan mengekspos foto, dengan gaya yang indah namun memancing masalah. Anak remaja berasumsi dengan mengupload foto sesuatu yang baik dan bangga dengan keindahan yang dimilikinya. Tetapi pada titik akhirnya keindahan itu dimanfaatkan oleh oknum yang tidak bertanggung jawab dengan terjadinya penculikan, kejahatan seksual, pembunuhan dan sebagainya.

Akibat dari kejahatan yang tidak bermoral, seperti penculikan dan kejahatan seksual memberikan lemahnya mental. Rasa takut saat bersosialisai di sekolah, di lingkungan sekitar, maka solusinya untuk mengembalikan mentalnya dengan kecerdasan spiritual yaitu menanamkan kembali nilai-nilai spiritual (Yulianto 2015).

Beberapa sampel tersebut terjadi, karena kurangnya nilai-nilai spiritual dan mengedepankan akhlak terpuji sehingga pengabaian dua hal tersebut memberikan kekacauan tersendiri. Pada akhirnya menyadari tidak bermaknanya hidup dengan meraih hawa nafsu dunia tersebut, sehingga mencari kembali nilai-nilai spiritual yang mampu menerapkan akhlakul karimah. Pentingnya nilai-nilai spiritual dan akhlaks pada diri manusia dalam membentengi keberadaan abad 21 yang penuh dengan hasrat kemewahan dunia, dapat mengerem hawa nafsunya untuk bijak dalam mengambil tindakan, hati yang selalu bersyukur. Sehingga dengan nilai spiritual yang melekat, apapun masalah yang terjadi, dimanapun keberadaanya, sedanga mengerjakan apa akan tetap menanamkan akhlak pada dirinya. Ketika akhlak sudah tertanam manusia akan meminimalisir untuk melakukan perbuatan tercela, dalam bertindak cerdas secara 
spiritual. Misal jiwa terhantui dengan harta yang berlimpah, hawa nafsu korupsi merangsang otak untuk bertindak. Letak kecerdasan spiritual yang telah tertanam memberikan rem bahwa korupsi itu dosa besar. Maka otak tersebut mengarahkan hati yang selalu bersyukur dan menerapkan akhlakul karimah dengan bersedekah.

\section{SIMPULAN DAN SARAN}

Pemaparan problematika saat ini perlunya pada diri manusia untuk dibentuk kecerdasan spiritual dan akhlak, sehingga untuk menyeimbangkan datangnya kemajuan teknologi atau modernisasi dapat terkendalikan hawa nafsunya. Kecerdasan spiritual dan akhlak juga sebagai obat solusi manusia yang terjerat dari huru hara kemoderna yaitu mengobati jiwa yang mati, hati yang kelam menjadi jiwa yang hidup dengan hati yang jernih serta selaras dengan pikiran yang terkendali oleh spiritual. Pembentukan tersebut, melalui jalan spiritual yaitu pendidikan tasawuf. Ujaibah mengemukakan bahwa pendidikan tasawuf adalah ilmu yang mempelajari tentang tata cara untuk mencapai Allah, membersihkan batin dari semua akhlak tercela dan menghiasinya dengan akhlak terpuji. Pendidikan tasawuf melalui materi-materi taubat, tawakal, wara', zuhud, sabar dan ridha serta mengamalkan shalat sunnah, puasa sunnah, dzikir, dan sebagainya. Jika pada kajian ini fokus Pendidikan Tasawuf Dalam Pembentukan Kecerdasan Spiritual Dan Akhlakul Karimah diharapkan kepada peneliti atau kajian selanjutnya fokus pada pendidikan tasawuf sebagai pendidikan kecerdasan emosional 


\section{DAFTAR PUSTAKA}

'Abd al-Karîm Ibn Hawazin al-Qusyairî. Al-Risâlah Al- Qusyairiyyah Fî Ilm AlTashawwuf. Kairo: Mathba'ah Muhammad 'Alî Shihâb Wa Aulâduh.

Ahmad Muttaqin. 2014. From Occultism to Hybrid Sufism: The Transformation of an Islamic-Hybrid Spiritual Group in Contemporary Indonesia. IJIMS, Indonesian Journal of Islam and Muslim Societies, 4 (1): 81-104.

Akhmad Muhaimin Azzet. 2010. Mengembangkan Kecerdasan Spiritual Bagi Anak. Jogjakarta: Katahati.

Al-Haramain, Elmansyah. 2011. "Shifting Orientation in Sufism : Its Development and Doctrine Adjustment in History." IJI 1 (2): 273-96.

Alavi, Hamid Reza. 2010. "Al - Ghaz ā Li on Moral Education Al-Ghaza ${ }^{-}$Li on Moral Education." Journal of Moral Education, no. December 2014: 37-41. https://doi.org/10.1080/03057240701552810.

Al-Sarraj. 1960. Al-Luma'fi Al- Tasawwuf. Kairo: Dar Al-Kutub Al-Hadithah.

Alfatih, Suryadilaga M. 2016. Ilmu Tasawuf. Yogyakarta : Kalimedia.

Ali Maksum. 2003. Tasawuf Sebagai Pembebasan Manusia Modern. Surabaya: PSAPM.

Ary Ginanjar Agustian. 2002. ESQ. Jakarta: Arga.

- 2008. Rahasia Sukses Membangun ESQ Power, Sebuah Inner Journey Melalui Ihsan. Jakarta: Penerbit Arga, 286-87.

Dadang Hawari. 2004. Al-Qur'an: Ilmu Kedokteran Jiwa Dan Kesehatan Jiwa. In Yogyakarta: Bhakti Prima Yassa.

Din Wahid. 2003. "Sufism and The 'Modern' in Islam." Studi Islamika 10 (3): 191-98.

Emmanuel Wora. 2006. “Theory, Culture and Post-Industrialization.” In Yogyakarta: Kanisius.

H.M. Jamil. 2007. MustafaCakrawala Tasawuf. Jakarta, Gaung Persada Press.

Haryati, Tri Astutik. 2012. "Modernitas Dalam Perspektif Seyyed Hossein Nasr." Jurnal Penelitian 8 (2): 307-24. https://doi.org/10.28918/jupe.v8i2.84.

Heck, Paul L. 2006. "Mysticim as Morality The Case Sufism." Journal of Religion Ethics, 253-86. 
Husen Mony. 2015. "Husen Mony: Meaning, Language, Dan Thought Remaja Pengguna Facebook...” Jurnnal Visi Komunikasi 14 (01): 132-51.

Howell, Julia D A Y. 2010. "Indonesia' s Salafist Sufis 1." Modern Asian Studies 5 (December 2009): 1029-51. https://doi.org/10.1017/S0026749X09990278.

Ibn 'Ataillah. Miftah Al-Faid Wa Misbah Al-Arwah. Mesir: Maktabah Muhammad Saw. Ali Al-Sabi,Wa Awladih,Tt.

Imam Al Ghozali.Ihya Ulum Al Din. Indonesia: Dar Ihya Al Kotob Al Arabi,Tt Jilid III.

Imam Hanafi. 2016. "Neurosains-Spiritualitas Dan Pengembangan Potensi Kreatif." AnNuha 3 (1): 25-38.

Isa, A. 2010. Hakikat Tasawuf. Bandung: Pustaka Hidayah.

Isma’il, I. et.al. 2008. Ensiklopedi Tasawuf Jilid I. Bandung: Angkasa.

Ja'far. 2016.Gerbang Tasawuf. Medan: Perdana Publishing.

M. Alfatih. 2016.Suryadilaga, Ilmu Tasawuf. Yogyakarta: Kalimedia.

Mahmud Yunus. 1989. Metodik Khusus Pendidikan Agama. Jakarta: Hidayah Karya Agung.

Majhudin. 2010. Akhlak Tasawuf Jilid I. Jakarta: KalamMulia.

Miswar. 2017. "Maqamat (Tahapan Yang Harus Ditempuh Dalam Proses Bertasawuf)." Jurnal ANSIRU PAI 1 (2): 8-19.

Miswar, dkk. 2016. Akhlak Tasawuf: Membangun Karakter Islam. Medan: Perdana Publishing.

Muhtarom, Ali. 2016. “'Anil Islam: Jurnal Kebudayaan Dan Ilmu Keislaman.” 'Anil Islam: Jurnal Kebudayaan Dan Ilmu Keislaman 9 (2): 247-67. http://jurnal.instika.ac.id/index.php/AnilIslam/article/view/17.

Mustofa, Ali. 2018. "Tasawuf Education As The Effort of Spiritual And Character Building Capability." Murobbi: Jurnal Ilmu Pendidikan 2 (1): 72-104.

Nata, Abuddin. 2014. "Akhlak Tasawuf Dan Karakter Mulia." In Jakarta: Raja Grafindo Persada, 173.

Ngainun Naim. 2013. "Kebangkitan Spiritualitas Masyarakat Modern.” Kalam: Jurnal Studi Agama Dan Pemikiran Islam 7 (2): 237-58. 
Novita, Eryanti. 2018. "Faktor-Faktor Yang Mempengaruhi Kebiasaan Menonton Film Porno Pada Remaja Eryanti Novita." Anthropos: Juranal Antropologi Sosial Dan Budaya 4 (1): 31-44.

Prasanti, Ditha, and Sri Seti Indriani. 2018. "Pelatihan Pengelolaan Konflik Organisasi Akibat Media Sosial Bagi Karang Taruna Di Desa Ciburial, Bandung." Jurnal $\begin{array}{lllll}\text { Pengabdian Pada } & \text { Masyarakat } & 3 & \text { (1): }\end{array}$ https://doi.org/10.30653/002.201831.45.

Rahmad Yulianto. 2014. "Tasawuf Transformatif Sebagai Solusi Problematika Manusia Modern Dalam Perspektif Pemikiran Tasawuf Muhammad Zuhri.” Teosofi: Jurnal Tasawuf Dan Pemikiran Islam 4 (1): 56-87.

Roger Geraudy. 1989. The Balance Sheet Of Western Philosophy in This Century, Dalam Toward Islamization of Disiplines.Malaysia: The Islamic Institute of Islamic Thought Islamization Knowledge Series.

Sidqi, Ahmad. 2015. "Wajah Tasawuf Di Era Modern: Antara Tantangan Dan Jawaban." Epistemé: Jurnal Pengembangan Ilmu Keislaman 10 (1). https://doi.org/10.21274/epis.2015.10.1.1-28.

Sodiman. 2014. "Menghadirkan Nilai-Nilai Spritual Tasawuf Dalam Proses Mendidik." Al-T'dib 6 (1): 330-44.

Suadi Putro. 2000. Mohammed Arkoun Tentang Islam Dan Modernitas. Jakarta: Paramadina.

Suciati. 2013. "Konseling Keluarga I-Cacho-E Untuk Mengurangi Kecanduan Bermain Game." Jurnal Bimbingan Konseling (Semarang) 2 (2). https://doi.org/10.15294/jubk.v2i2.2727.

Sukidi. 2002. Rahasia Sukses Hidup Bahagia Kecerdasan Spiritual Mengapa SQ Lebih Penting Dari Pada IQ dan EQ. Jakarta: PT. Gramedia Pustaka Utama.

Suryaningsih, Iin. 2013. "Al-Ḥaqīqah Al-Muwāfaqah Li Al-Sharī'ah: Al-Tașāluh Bayn Al-Tașawuf Wa Al-Sharī'ah Bi Nusantara? Al-Qarn Al-Sādis 'Ashr Al-Mīlād̄̄ Abstract:" Studi Islamika 20 (1).

Sutomo, Imam. 2014. "Modification of Character Education into Akhlaq Education for the Global Community Life." IJIMS, Indonesian Journal of Islam and Muslim Societies, 4 (2): 291-316.

Syamsun, Ni'am. 2014. Tasawuf Studies: Pengantar Belajar Tasawuf.Yogyakarta: ArRuz Media. Media. 
Totok Jumantoro dan Samsul Munir. 2012. Kamus Ilmu Tasawuf. Wonosobo, amzah.

Ubaedillah, Achmad. 2015. "Sufi Islam and the Nation State: Darul Arkam Movement in the Post Suharto Era of Indonesia." IJIMS, Indonesian Journal of Islam and Muslim Societies 5 (1): 79-110.

Udik Abdullah. 2005. Meledakkan IESQ Dengan Langkah Taqwa Dan Tawakkal. Jakarta: Zikrul Hakim.

Yulianto, Rahmad. 2015. "Tasawuf Transformatif Muhammad Zuhri Solusi Problematika Manusia Modern.” Al-Hikmah: Jurnal Studi Agama-Agama 1 (1).

Vogel, Ann. 2012. "Sufism.” The Wiley Blackwell Encyclopedia OfRace, Ethnicity, and Nationalism, First Edition., 1-4.

Waleed Ziad. 2016. "Sufism." The Wiley Blackwell Encyclopedia OfRace, Ethnicity, and Nationalism, First Edition., 1-3. https://doi.org/10.1002/9781118663202.wberen468. 